\title{
KNOWLEDGE ALLIANCE AS EDUCATION SERVICES: UPDATED CONTENT OF INTEGRATED FLIGHT PREPARATION AND TRAINING OF PILOTS
}

\author{
Hélia Némethová ${ }^{1}$, Stanislav Szabo $^{2}$, Róbert Rozenberg $^{3}$
}

\begin{abstract}
The article examines the current aspects of new education and training of pilots within the Knowledge Alliance of Aviation Education as the State-Privat Partnership in the Education Services in the conditions of the Slovak Republic. This article represents the part of the feasibility study. In order to ensure the continuity, quality and safety in the aviation education of future military and civil pilots as the aviation professionals, research works of a similar nature are needed. This article used analysis and synthesis tools, the method "per partes" (integration in parts) and the expert method. Authors solved the following praxeological questions: Which entity is competent and eligible for the comprehensive training of pilots as professionals? What kind of organization of education processes will ensure the required output and efficient use of available public and private resources? The answers to the praxeological issues are presented as the proposal of content of integrated flight preparation and training of pilots under the key leadership of the Air Force and their state, public and private partners. The output of the article is the proposal for the new content of the education and training of pilots.
\end{abstract}

UDC Classification: 378, DOI: 10.12955/cbup.v7.1413

Keywords: service, safety, education,knowledge alliance, aviation, situational management

\section{Introduction}

On January 27, 2016, a contract for the cooperation between the Ministry of Defence of the Slovak Republic, the Armed Forces Academy of Milan Rastislav Stefanik and the Technical University in Kosice was signed at the Faculty of Aeronautics of the Technical University in Kosice, with the aim of providing auniversity education for cadets of the General Staff of the Academy of General Milan Rastislav Stefanik in aeronautical study programs of the 1st and 2nd level at the Faculty of Aeronautics of the Technical University in Kosice. It is a demonstration of the confidence of the Defence Sector representatives in its scientific and pedagogical team and, at the same time, as an opportunity to establish a rich tradition of aviation education, research, development and expertise. The Faculty of Aviation was founded on 01/02/2005 as the ninth faculty of the Technical University in Kosice. Its origin was the result of the long-term transformation of the military university education in the Slovak Republic and was connected with the effort to preserve the long-term tradition of flying and higher education of pilots and aviation technical staff in Kosice, which until 2004 had been provided for more than 30 years by the Air Force Academy. M.R. Stefanik in Kosice. Aviation education follows a whole-class trend where education, science, research and innovations are the most important pillars of a knowledge-based society, the achievement of which is indispensable for achieving the sustainable development of our society. A natural response is that the educational institutions are the important actors in the processes where only the interconnection of scientific, educational and innovation activities can be a real accelerator of society.In order to ensure the continuity, quality and safety in the aviation education of future military and civil aviation professionals, the research works and especially doctoral thesis of a similar nature are needed.

The main objective of this article is to create a proposal for the new content of education and training of pilots in the conditions of a public-private partnership as services for the realization of goals in the field of education and training of Air Force Pilots of the Slovak Armed Forces, with emphasis on the building and development of required personnel competencies, on the basis of the sixty years of knowledge incivilian and military aviation.

We have the following praxeological questions: Which entity is competent and eligible for the comprehensive training of pilots asprofessionals? What kind of organization of education processes will ensure the required output and efficient use of available public and private resources? What will be the new content of education of pilots that draws on past experience and that will respond to new challenges in the aviation sector and will enable the application of the SafetyFirst principle? Our assumption is that for the needs of a state such as the Slovak Republic for the continuous training of

\footnotetext{
${ }^{1}$ Technical University of Košice, Faculty of Aeronautics, Department of Flight preparation, Košice, Slovakia, helia.nemethova@tuke.sk

${ }^{2}$ Technical University of Košice, Faculty of Aeronautics, Košice, Slovakia, stanislav.szabo@tuke.sk

${ }^{3}$ Technical University of Košice, Faculty of Aeronautics, Department of Flight preparation, Košice, Slovakia, robert.rozenberg@tuke.sk
} 
pilots as professionals the optimal solution is the realization of state-private cooperation and partnership as a service of the knowledge alliance of aviation education.

The updated content of integrated flight preparation and training of pilots respects a new description in the study field of "Transportation", led by the Dean of the Faculty of Aeronautics Assoc. Prof. Stanislav Szabo.

\section{Literature review: Research theoretical framework of Knowledge Alliance for the new education content}

The strong foundation of education of pilots lies in the applied management, economy, social sciences and the applied technical sciences that form the engineering basis of flight preparation and training of future pilots, technicians and other aviation specialists. Aviation education has a much wider meaning than just the education and training of pilots.

The core elements of education and training of pilots as a part of the Knowledge Alliance of Aviation Education and as the State-Privat education service presented in the Table 1.

Table 1: The core elements of pilot education and training

The basic acts of civil and military aviation law for the education of aviation personnel, the acts which are the base for the described process at the national and international level

Aviation knowledge, research and subjects according to the Annex I - Part FCL, Syllabus of theoretical knowledge for the Air Transport Pilot Licence, Commercial Pilot Licence and Instrument Rating (EASA, 2016)

Aviation knowledge, research and subjects according to the Commission Regulation (EU) 2015/340 (EASA, 2015), laying down the technical requirements and administrative procedures relating to the air traffic controllers' licences and certificates

Aviation knowledge, research and know-how concentrated within the PEGASUS consortium of aerospace engineering universities and faculties in the EU https://www.pegasus-europe.org/ (Delft, 2007

The know-how, the past and present Civil and Military aviation maintenance, repair and operation's experience

The results of the theoretical work and the scientific and research activities in the field of : University Academic subjects, Social and Human Sciences, the Simulation and modelling of Security issues, the Applied Technical Sciences, the Applied Civil and Military / Air Force management, education and training etc. within the Expert Database of Civil and Military Aviation Experience in progess.

Source: Authors

The selected theoretical frameworks of the Knowledge Alliance within the issues of Simulation and modelling of Security can be found within the work by Fuchs et al. (2010) focused on the simulation of dangerous substance outflows into the environment a result of traffic accidents by dangerous substances transport; in the study by Dvorak et al. (2010) on the enhancing of security on critical accident locations using telematics support; in the work by Balatka et al. (2011) on the exposure of the environment and surface water todangerous liquids - the slop outflow model; in the study by Kelemen and Blištanová (2014) on the applied knowledge in logistic modelling to handle the threat of floods with aviation logistic support; in the study by Kompis et al. (2011) on the parallel computational models for composites reinforced by CNT-fibres for personal and vehicle protection materials; in the work by Vágner and Papová 2014) on the comparison of Radar Simulator for Air Traffic Control used also for the education of new Air Traffic Controllers; in the work by Pavolová and Tobisová (2013) on the model of supplier quality management in the transport company applied for air transport; in the study by Kuzma et al. (2016) on the use of the CAX System as a tool for modeling construction elements in the aviation industry; or in the work by Fözö et al. (2009) on the advanced anytime control algorithms and the modeling of turbojet engines etc.

The selected theoretical frameworks of the Knowledge Alliance within the Applied Technical Sciences are within the work by Nečas and Kelemen (2009) on the call for more security in the technology revolution: in the work by Bučka and Kelemen (2009) on the analysis of the specific requirements related to the Slovak Air Force; in the book by Hovanec (2016) on the digital factory as a prerequisite for successful application in the area of ergonomics and the human factor; in the study by Andoga et al. (2018) on the intelligent situational control of small turbojet engines; in the work by Draganova et al. (2017) on the non-stationary noise analysis of magnetic sensors using allan variance; 
in the study by Semrad et al. (2014) on the analysis of all composite wing design containing magnetic microwires; or in the works by Polishchuk et a. (2019) on the evaluation of start-ups projects etc.

The selected theoretical frameworks of the Knowledge Alliance within the Applied Civil and Military / Air Force management, education and training are within the work by Socha et al. (2016) on the training of pilots using a flight simulator and its impact on piloting precision; in the study by Rozenberg et al. (2016) on the critical elements in piloting techniques in aerobatic teams; in the work by Durco et al. (2017) on the means of using CPDLC with ATC procedures in a terminal maneuvering area; in the study by Nečas et al. (2009) on information operations and media: Beyond the Security Scope; in the analysis by Kalavsky et al. (2015) on the conditions for the abandonment of a helicopter using a personal rescue parachute; in the work by Sopoci et al. (2009) on the Air Force knowledge within the Military Management in the 21 century and the Transformation of the Army etc.

\section{Identification of problem and methodology}

The main problem is the new professional content of education and training of pilots within the Knowledge Alliance of Aviation Education as the State-Privat Partnership Service in the conditions of the Slovak Republic.

We used the tools of analysis and synthesis of the education, with the method "per partes" (integration in parts) in the aviation practice.

The historical analysis of the contents of flight preparation and pilot training was carried out on the data basis of the selected institutionsfrom 1959 until the present in the Table 2.

\begin{tabular}{|l|l|}
\hline \multicolumn{1}{|l|}{ Table 2: Institutions } \\
\hline Vojenské letecké účilište Košice (Military aviation school in Košice, Slovakia) \\
\hline Vojenská stredná škola letectva v Košiciach (Military Hight School in Košice, Slovakia) \\
\hline Odborná výcviková škola letectva Košice (Professional Training School of Air Force Košice, Slovakia) \\
\hline $\begin{array}{l}\text { Vysoká vojenská letecká škola SNP v Košiciach (Military Aviation College of Slovak National Uprising in } \\
\text { Košice, Slovakia) }\end{array}$ \\
\hline $\begin{array}{l}\text { Vojenská letecká akadémia gen. Milana Rastislava Štefánika v Košiciach (Air Force Academy of Gen. M. } \\
\text { R. Šefánik in Košice, Slovakia) }\end{array}$ \\
\hline $\begin{array}{l}\text { Letecká fakulta Technickej univerzity v Košiciach (Faculty of Aeronautics, the Tehchnical University of } \\
\text { Košice, Slovakia) }\end{array}$ \\
\hline Lotnicza Akademia Wojskowa - "Szkoła Orląt" (Air Force Academy in Deblin, Poland) \\
\hline $\begin{array}{l}\text { Univerzita obrany, Fakulta vojenských technológií, the Czech Republic (University of Defeence, Faculty of } \\
\text { Military Technology, teh Czech Republic) }\end{array}$ \\
\hline École de l'air, Salon-de-Provence, France (French Air Force Academy) \\
\hline Source: Authors \\
\hline
\end{tabular}

The lessons learned from the historical analysis were compared with the findings gained by the expert method. The expert group consisted of 5 specialistsexperienced in the content of aviation education and pilot training. The data were obtained throughinterviews with the experts.

The added value of the research is in the identification, historical analysis and expert evaluation of data on the content of aviation education in Košice (within the former Czechoslovakia to the present), the identification of common elements of theoretical flight training, synthetic training and practical flight training. The research results represent the first part of the study for the elaboration of a longterm plan for the development of aviation education for the Slovak Air Force in 2020-2030.

The study plans from the historical archives of Military Aviation College of Slovak National Uprising in Košice, the Air Force Academy of Gen. M. R. Šefánik in Košice, and the Faculty of Aeronautics, the Tehchnical University of Košice, were the main data sources.Data collection for the study of the issue was carried out during 2018/2019. The origin of the analyzed material is in the database of 60 years of aviation education within the Czechoslovakia and the Slovak Republic. Our national experience, including personal experience, has been compared and complemented by the successful experience of the aeronautical training abroad (Czech Republic, Poland, France). In 2018, the training of foreign pilots began as a part of the state-private educational service in Slovakia. The Faculty of Aeronautics of the Technical University in Košice is a part of this international educational consortium based in Košice. These new findings have affected the results presented in the article. 


\section{Results and Discussion}

The theoretical flight preparation of pilots, synthetic training tools / training on the simulators, practical flight training and emergency training (ET), are three crucial subsystems of Integrated Flight Preparation and Training IFPT. The form and content of pilot preparation and training should meet the requirements of professional competence to perform the functions of aviation personnel, with an emphasis on:

Theoretical Flight Preparation of Pilots:professional theoretical preparation of the Armed Forces of the Slovak Republic;basic theoretical flight training of pilots, in accordance with the requirements of the European Agency for Safety of Aviation (EASA);basic and special theoretical flight preparation of a military pilot, in accordance with the operational requirements of the NATO Air Force pilots and NATO standards, as part of a specialized theoretical module, preparation of the material part of aviation equipment used for flight training.

Means of synthetic pilot training / training on simulators:for the computer-aided pilots training;the air training simulators for flight operations training;theair simulators for flying tasks focusing on instrumentation piloting and simulation of flight tasks for combat use (According to the US Federal Aviation Administration FAAAviation Training Device (ATD), FAA Basic ATD (BATD), FAA Advanced ATD (AATD),Flight Training Devices (FTD),Full Flight Simulators (FFS).According to the European Aviation Safety Agency (EASA)Flight Navigation and Procedures Trainer (FNPT),Flight Training Devices (FTD),Full Flight Simulators (FFS).

Practical training (Flight and emergency training of aborting airplane / emergency training ET):

the entry and selection flight training of airplane and helicopter pilots; the basic flight training of airplane and helicopter pilots; the continuing flight training of airplane and helicopter pilots; the flight training of airplane and propeller aircraft pilots in emergency training - ET (under different conditions).

The Integrated Flight Preparation and Training is characterized by a decentralized hierarchical management structure, with a decisive share of the human factor in the decision-making and management process, in line with the active and cooperative links of the relatively autonomous elements (pilots) of preparation and training of pilots.

The preparation of the pilot fromthe Slovak Republic consists of professional theoretical preparation and practical military training, whose structure can be expressed as follows (see Figure 1):

Professional theoretical training: the combined arm theoretical preparation; the specialized theoretical preparation of the components of the AF SR (Air Force); the theoretical flight preparation for flight training.

\begin{tabular}{|l|}
\hline Figure 1:Model of integrated flight preparation and training of pilots (IFPT) Situational classes \\
TFP Theoretical Flight Preparation of pilots - 1st Situation class \\
SPT Synthetic Pilot Training tools / training on simulators - 2nd Situation class \\
PT PracticalTraining (flight preparation and training after emergency \\
training ET) - $3^{\text {rd }}$ Situation class \\
\hline Source: Authors
\end{tabular}

Practical training: the combined arm training of individual / units (the basic professional training of components of the AF SR, the entry, selection and basic flight training pilots, the survival training 
after an emergency flight); operational training of the Air Force of the SR (the continuing flight training for pilots, the combat flight training for pilots), the retraining in the AF SR on the new military aviation technique, procedures and methodology of training, the equipment, armaments, military systems, etc., the preparation for performing a function in anothersection of the AF SR.

Theoretical preparation is done in the form of lectures, seminars and exercises. The emergency flight training is organized in both winter and summer conditions, both day and night. Forms of individual preparation and training in organic flight crews (according to conditions) are conducted. Pilot flight training is conducted in the form of individual training (such as individual flight training) and training of air units (such as combat-oriented unit training).

By training we understand:according to the means of training used, such astraining by using the synthetic means of training (flight simulators), the practical flight training using aviation technology; according to daily training time (day flight training, the flight training at night); according to the rules of flight (the flight training according to the flight rules for the country's visibility, the flight training according to instrument flight rules); according to meteorological conditions of flight (the flight training in visual meteorological conditions of flight for VMC visibility, the flight training in IMC instrument flight conditions); by the type of training (the training in pilotage techniques, navigational training - line flights / navigation flights, training in the combat use by type of aviation of the Air Force of the SR); the individual training to obtain a combat pilot training class (3rd class pilot in weather conditions of VMC during the day, a 2nd class pilot in all meteorological conditions during the day and under VMC meteorological conditions at the night, a 1st class pilot in all day and night weather conditions); training of an individual to obtain an instructor's authorization (flight training instructor in sequence and in the range of daily and meteorological flight conditions, as in class pilot training), the instructor training on an air simulator, an inspector of a certain type of the Air Force of the SR); the unit training in the group flights of airplanes or helicopters (the training of a pair of airplanes or helicopters, the training flights of airplanes or helicopters, the training in a squadron).

The Integrated Flight Preparation and Training System functions as a comprehensive, professional training of specialized aeronautical personnel to carry out the specified flight tasks at an acceptable level of flight safety with the required final quality of the preparation and training process, with the maximum efficiency of the human, material, technical and financial resources used.

Implementation of the target function of the system is generally ensured through the practice of steady, following partial system management functions:planning function,operational function,monitoring function, a reaction function, and a coordination function.

For the creation of specific algorithmic and programmable units, it is generally desirable to perform a further decomposition of partial control functions according to the expert knowledge:operational situations,time factor,an organization's management hierarchy (an integrated flight training and pilot training system).

Under the conditions of the Slovak Republic, the joint aviation education of civilian and military aviation personnel is again implemented from the academic year 2016/2017. The executives are authorized state, public and private entities that make up the Knowledge Alliance of Aviation Education, which is actively involved in creating a professional description of the integrated study field 6 Transport. This issue presents another separate article.

The Knowledge Alliance of Aviation Education is a consortium of authorized state, public and private entities that are oriented towards the training of personnel for the pursuit of professions and licensed activities in Civil and Military Aviation, the air transport and space vehicles in transport, in the design, maintenance, and operation of relevant technologies in particular modes of transport, and in the transport services, according to the relevant international and national standards / regulations.

The executives are the following authorized state, public and private entities that make up the Knowledge alliance of Aviation Education, at the platform in Table 3.

\section{Conclusion}

This article meets the main goal of pedagogical research to create a proposal for the new content of education and training of pilots in the conditions of the public-private partnership as services for the 
realization of goals in the field of education and training of Air Force Pilots of the Slovak Armed Forces, with emphasis on the building and development of required personnel competencies.

\begin{tabular}{|l|}
\hline Table 3: The Knowledge Alliance of Aviation Education \\
\hline State and Public entities of the Knowledge Alliance \\
\hline Technical University of Kosice, Faculty of Aeronautics, Slovakia \\
\hline $\begin{array}{l}\text { The contracting partner, Armed Forces Academy of General Milan Rastislav Stefanik in Liptovsky } \\
\text { Mikulas / Ministry of Defence of the Slovak Republic }\end{array}$ \\
\hline The Air Force of the Armed Forces of the Slovak Republic / Armed Forces of the Slovak Republic \\
\hline University of Zilina, Faculty of Business, Economics, Transport and Communications, Slovakia \\
\hline Selected aircraft maintenance training organizations \\
\hline Air traffic services of the Slovak Republic, Ltd. Bratislava \\
\hline Private entities of the Knowledge Alliance \\
\hline $\begin{array}{l}\text { Slovak Training Academy, Ltd. - a contractor for practical flight training of helicopter pilots / at present } \\
\text { the foreign pilots }\end{array}$ \\
\hline AirJob, Ltd., JetAge, Ltd. - contractual partners for the practical flight training of airplane pilots \\
\hline Selected aircraft maintenance training organizations \\
\hline Source: Authors \\
\hline
\end{tabular}

The theoretical flight preparation of pilots is based on the three crucial subsystems of Integrated Flight Preparation and Training IFPT. The form and content of pilot preparation and training should meet the requirements of professional competence to perform the functions of aviation personnel, with an emphasis on:Theoretical Flight Preparation of Pilots;Means of synthetic pilot training / training on simulators; Practical training (Flight and emergency training of aborting airplane / emergency training ET).

The Armed Forces Academy in Liptovský Mikuláš, which is responsible for the preparation of cadets for the Slovak Air Force, has signed a contract with the Faculty of Aviation of the Technical University of Košice (see the Act of the National Council of the Slovak Republic No. 455/2004 Coll. of 30 June 2004).

The Ministry of Defense of the Slovak Republic has announced a grant for a feasibility study of the training of aviation personnel for the Slovak Air Force (see the Public callfor the submission of applications for subsidies for research and development projects in support of national defenseCall 12018). For this reason, this article is only a small part of this feasibility study in progress. The feasibility study will include a historical analysis and assessment of the experience of aviation education content. The second part of the study will explore the possibilities of the state and private entities in the air education of personnel for the Air Force. The third part of the study will include a proposal of updated knowledge, skills and competences of aeronautical personnel based on research experience, the Air Force requirements and the new trends.

The results of the research will be used for the elaboration of a long-term plan for the development of aviation education in the years 2020-2030, which will be implemented by the Faculty of Aviation of the Technical University in Košice in cooperation with the Armed Forces Academy and the Slovak Air Force.The Knowledge Alliance of Aviation Education is eligible for the comprehensive training of pilots as aviation professionals.

The alliance partners' joint efforts make it possible to diversify the risks, share the praxeological problems of training processes and the pilot training, share the resources for problem solving and ensure the quality outputs.The proposals of education and training of pilots are based on the experience of 60 years of aviation education. Aviation education has a much wider meaning than only the education and training of pilots. The new content will respond to new challenges in the aviation sector and the special requirements of the Air Force. All past, current and new aviation knowledge will be focused on the perspectiveInternational Expert Database of Civil and Military Aviation Experience that is still in progress.

\section{Acknowledgements}

Article was prepared in the framework of the institutional project "Integrated Aviation Education of Civilian and Military Personnel at the Faculty of Aeronautics, the Technical University of Košice, SR", in 2019-2020. 


\section{References}

Andoga, R., Fozo, L., Judicak, J., Breda, R., Szabo, S., Rozenberg, R., \& Dzunda, M. (2018). Intelligent Situational Control of Small Turbojet Engines. International journal of Aerospace Engineering, 2018, 1-16. doi:10.1155/2018/8328792

Annex I - Part FCL. Syllabus of theoretical knowledge for the Air Transport Pilot Licence, Commercial Pilot Licence and Instrument Rating, EASA, Brussels, Belgium, 2016. Retrieved from https://www.easa.europa.eu/sites/default/files/dfu/PartFCL.pdf

Balatka, M., Fuchs, P., Kamenicky, J., Sousek, R., \& Kelemen, M. (2011). Exposure of the environment and surface water by dangerous liquid - the slop outflow model. In Sánchez, M. (ed.), 15th World Multi-Conference on Systemics, Cybernetics and Informatics, Proceedings, Volume III, Orlando, Florida, USA, July 19th - July 22nd, 2011, 280-284.

Bučka, P., \& Kelemen, M. (2009). Requirements related to the Slovak Republic's Air Force. In Vintr, Z. (ed..), International conference on Military Technologies, ICMT '09 [electronic source], Brno, Czech Republic, May 5-9, 2009, 282-289.

Draganová, K., Moucha, V., Volcko, T., \& Semrád, K. (2017). Non-Stationary Noise Analysis of Magnetic Sensors using Allan Variance. Acta Physica Polonica, 131(4), 1126-1128.

Drotárová, J., Kačíková, D., Kelemen, M., \&Bodor, M. (2016). The possibilities of using blended learning in fire safety education. In CBU international conference proceedings 2016: innovations in science and education: March 23-25, 2016, in Prague, Czech Republic. Vol. 4; eds. Tavleen Sahota, Mary-Anne Jones. ISBN 978-80-88042-05-1. ISSN 1805-997X. p. 283-286.

Dvorak, Z., Cekerevac, Z., Kelemen, M., \& Sousek, R. (2010). Enhancing of security on critical accident locations using telematics support. In Sánchez, M. (ed.), International conference on society and information technologies, ICSIT 2010 proceedings, Orlando, Florida, USA, April 6th-9th, 2010, 414-417.

Ďurčo, S., Sabo, J., Rozenberg, R., \& Miženková, Ž. (2017). Means of CPDLC using with ATC procedures in terminal maneuvering area. In Hrubý, M. (eds.), Distance Learning, Simulation and Communication 2017, proceedings, Brno, Czech Republic, May 5-9, 2017, 62-67.

EASA, Commission Regulation (EU) 2015/340 of 20 February 2015, Brussels, Belgium, 2015. Retrieved from https://www.easa.europa.eu/document-library/regulations/commission-regulation-eu-2015340

Fuchs, P., Novak, P., Saska, T., Smida, J., Dvorak, Z., Kelemen, M., \& Sousek, R. (2010). Simulation of dangerous substances outflows into the environment because of traffic accidents by dangerous substances transport. In Sánchez, M. (ed.), the 14th world multi-conference on systemics, cybernetics and informatics, WMSCI 2010 proceedings, volume 1, Orlando, Florida, USA, June 29th - July 2nd, 2010, 204-207.

Fözö, L., Andoga, R., \& Madarász, L. (2009). Advanced anytime control algorithms and modeling of turbojet engines. In Rudas, I.J., Fodor, J. \& Kacprzyk, J. (eds.), Computational intelligence and informatics, the 10th international symposium of Hungarian researchers, proceedings, Budapest, Hungary, November 12-14, 2009, 83-94.

Hovanec, M. (2016). Digital factory as a prerequisite for successful application in the area of ergonomics and human factor. Theoretical Issues in Ergonomics Science, 18(1), 35-45.

Kal’avský, P., Socha, V., Socha, L., Kutílek, P., Gazda, J., \& Kimličková, M. (2015). Conditions for Abandonment Out of a Helicopter Using Personal Rescue Parachute. In Stefek, A. \& Krivanek, V. (eds.), International Conference on Military Technologies Location, Book Series: International Conference on Military Technologies, Brno, Czech Republic, MAY 1921, 2015, 467-471.

Kelemen, M., \& Blišt'anová, M. (2014). Logistic Modelling to handle the Threat of Floods - The Bodva River example. In Curran Associates, Inc. (eds.), 14th International Multidisciplinary Scientific GeoConference, SGEM 2014 Conference Proceedings, Volume III, Sofia, Bulgaria, June 17-26, 2014, 715-723.

Kelemen, M. (2017). Security of the Slovak Republic and issues of protected interests: Security and criminal law research topics. In Fire protection, Seafety and Security 2017. International Scientific Conference Proceedings, May 3rd. - 5th., 2017, Zvolen, Slovak Republic. Editors Majlingová, A, Vel'ková, V. Zvolen: Technical university, 2017. ISBN 978-80-2282957-1. 312-316.

Kelemen, M., Nečas, P., \& Terem, P. (2010). Advanced aerospace management of integrated education and training towards comprehensive security. Incas Bulletin, 2 (3/2010), 45-49.

Kelemen, M., Nečas, P., Bučka, P., \& Boscoianu, M. (2011). Situational control methods of Aviatic didactic flight safety regulations system. In A ZMNE KLHTK tudományos folyoirata, 4 (1/2011), 18-21.

Kelemen, M., Szabo, S., \& Vajdová, I. (2018). Cybersecurity in the Context of Criminal Law Protection of the State Security and Sectors of Critical Infrastructure. In CNDCGS 2018 International Scientific Conference, 25.04.2018-27.04.2018, Litva. SIGN-TUKE 197361 // Challenges to national defence in contemporary geopolitical situation: proceedings / Bekesiene, S. (editor); Hošková-Mayerová, Šárka (editor). - Vilnius (Litva): The General Jonas Žemaitis Military Academy, 2018. ISSN (online) 2538-8959. 100-104.

Kelemen, M., Szabo, S., \& Vajdová, I. (2018). Security Management in the Air Transport: Example of an Interdisciplinary Investigation of Special Security Questions. In CNDCGS 2018 International Scientific Conference, 25.04.2018-27.04.2018, Litva, Challenges to national defence in contemporary geopolitical situation: proceedings / Bekesiene, S. (editor) ; HoškováMayerová, Šárka (editor). - Vilnius (Litva): The General Jonas Žemaitis Military Academy, 2018. ISSN (online) 2538-8959. 105-108.

Kelemen, M., Pilát, M., Makó, S., Rozenberg, R., \&A. Tobisová. (2019). Pricing Policy Aspects in Competitive Fight Between Low-Cost Airlines on Kosice Airport. Journal of Konbin, Vol. 49, 1(2019), 331-342. doi:10.2478/jok-2019-0017 
Kompis, V., Qin, QH., Fu, ZJ., Chen, CS., Droppa, P., Kelemen, M., \& Chen, W. (2012). Parallel computational models for composites renforced by CNT-fibres. Engineering Analysis with Boundry Elements, Vol. 36, 1/2012, 47-52.

doi:10.1016/j.enganabound.2011.04.009

Kuzma, D., Korba, P., Hovanec, M., \& Dulina, L. (2016). The Use of CAX System as a Tool Modeling Construction Element in the Aviation Industry. Naše more, 63(3) SI, 134-139.

Nečas, P., \& Kelemen, M. (2009). Call for more security: Technology revolution wanted. In in Vintr, Z. (ed.), International conference on Military Technologies, ICMT '09 [electronic source], Brno, Czech Republic, May 5-9, 2009, 246-250.

Nečas, P., Kelemen, M., \& Sopóci, M. (2009). Information operations and media: Beyond the Security Scope? In Stanciu, L. (ed.), $15^{\text {th }}$ International Conference the Knowledge-based Organization: Military Sciences. Security and Defence, Conference Proceedings 1, Sibiu, Romania, November 26-28, 2009, 96-103.

Pavolová, H., \& Tobisová, A. (2013). The Model of Supplier Quality Management in Transport Company, Naše more, 60 (5/6), 123-126.

PEGASUS consortium of Aerospace Engineering Universities, Delft., Netherlands. Retrieved from https://www.pegasuseurope.org/

Petlák, E. (2004). General Didactics. Bratislava: Martinus.

Polishchuk, V., \&M. Kelemen. (2019). Information Model of Evaluation and Output Rating of Start-up Projects Development Teams. In Luengo, D. et al. (ed.)Proceedings of the Second International Workshop on Computer Modeling and Intelligent Systems (CMIS-2019), Zaporizhzhia, Ukraine, April 15-19, 2019. CEUR Workshop Proceedings Vol. 2353, CEUR-WS.org 2019, 674-688. Retrieved from http://ceur-ws.org/Vol-2353/paper54.pdf

Polishchuk, V., Kelemen, M., \&Kozuba, J. (2019). Technology Improving Safety of Crowdfunding Platforms Functioning in theContext of the Protection of the Start-Up Investors in the Financial and Transport Sectors. Journal of Konbin, Vol. 49, 1(2019), 313-330. doi:10.2478/jok-2019-0016

PEGASUS consortium of Aerospace Engineering Universities, Delft., Netherlands. Retrieved from https://www.pegasuseurope.org/

Rozenberg, R., Socha, V., Socha, L., Szabo, S., \& Němec, V. (2016). Critical elements in piloting techniques in aerobatic teams. In Ostaševičius, V. (ed.), Transport Means 2016 - Proceedings of the International Conference, Kaunas, Lihuania, October 5-7, 2016, 444-449.

Sample of Field Description. (2008). Bratislava, Slovakia: Ministry of Education, Science, Research and Sport, 2008.

Semrád, K., Lipovský, P., Cernan, J., \& Jurčovič, M. (2014). Analysis of all composite wing design containing magnetic microwires. In Trebuňa, F. (ed.), Modelling of Mechanical and Mechatronic systems, $6^{\text {th }}$ Conference on Modelling of Mechanical and Mechatronic systems (MMaMS), Vysoké Tatry, Slovakia, November 25-27, 2014, 428-434.

Socha, V., Socha, L., Szabo, S., Hanak, K., Gazda, J., Kimlickova, M., Vajdova, I., Madoran, A., Hanakova, L., Nemec, V., Puskas, T., Schlenker J., \& Rozenberg, R. (2016). Training of pilots using flight simulator and its impact on piloting precision. In Ostaševičius, V. (ed.), Transport Means 2016, Proceedings of the International Conference, Kaunas, Lihuania, October 5-7, 2016, 374-379.

Sopóci, M., Kelemen, M., \& Nečas, P. (2009). Military Management in 21 century and Transformation of Army. In Stanciu, L. (ed.), $15^{\text {th }}$ International Conference the Knowledge-based Organization: Military Sciences. Security and Defence, Conference Proceedings 1, Sibiu, Romania, November 26-28, 2009, 138-142.

Szabo, S., Makó, S., Tobisová, A., Hanák, P., \&Pilát, M. (2018). Effect of the load factor on the ticket price. in Problemy Transportu = Transport Problems $:$ International Scientific Journal . Gliwice (Pol'sko): Politechnika Slaska Roč. 13, č. 3 (2018), pp. 39-47. Available online: http://transportproblems.polsl.pl/pl/Archiwum/2018/zeszyt3/2018t13z3_04.pdf...

Szabo, S., Pilát, M., Tobisová, A., \&Makó, S. (2019). Operational statistics of Kosice Airport, in Scientific Journal of Silesian University of Technology: Zeszyty Naukowe Politechniki Ślaskiej: Series Transport: Seria Transport. Katowice (Pol'sko): Wydział Transportu č. 102 (2019), pp. 197-203. Available online:

http://sjsutst.polsl.pl/archives/2019/vol102/197_SJSUTST102_2019_SzaboPilatTobisovaMako.pdf...

Turek, I. (2004). Innovation in Didactics. Bratislava: MPC, 2004.

Urban, R., Štroner, M., Blistan, P., Kovanič, L., Patera, M., Jacko, S., Ďuriška, I., Kelemen, M., \& Szabo, S. (2019). The Suitability of UAS for Mass Movement Monitoring Caused by Torrential Rainfall - A Study on the Talus Cones in the Alpine Terrain in High Tatras, Slovakia. ISPRS Int. J. Geo-Inf. 2019, 8, 317. doi:10.3390/ijgi8080317

Vágner, J., \& Pappová, E. (2014). Comparison of Radar Simulator for Air Traffic Control. Naše more, 61(1-2), 31-35. 